\title{
JUNIOR HIGH SCHOOL STUDENTS' SELF-REGULATED LEARNING
}

\author{
Nitiasih, P.K. \\ English Language Education, Faculty of Language and Art \\ Ganesha University of Education \\ Singaraja, Indonesia \\ e-mail: titiekjegeg@gmail.com \\ Mahayanti, N.W.S. \\ English Language Education, Faculty of Language and Art \\ Ganesha University of Education \\ Singaraja, Indonesia \\ e-mail: mahayantisurya@yahoo.co.id \\ Wijayanti, N.P.R. \\ English Language Education, Faculty of Language and Art \\ Ganesha University of Education \\ Singaraja, Indonesia \\ e-mail: radhawijayanti@gmail.com
}

\begin{abstract}
In this globalisation era, being able to manage our own learning is a mist and selfregulated learning can be the answer for making the students be able to do so. Identifying self-regulated learning implemented by the students of Junior High School in Buleleng sub-district and also identifying self-regulated aspects which were mostly implemented by Junior High School students in Buleleng sub-districtwerethepurposesofthis study. A total of 444 students from JuniorHighSchoolswhichhaveimplementedcurriculum 2013 were taken as the subjects of this study. Asaqualitativeresearch, the instruments used in this study were observation checklist, questionnaires and also interview guide. The result of the study shows that $78 \%$ of Junior High School students in Buleleng sub-district haveimplemented self-regulated learning and there aretwo aspects of self-regulated learning which aremostly implemented by the students, theyareself-judgment and selfreaction in which those two aspects are in self-reflection phase.
\end{abstract}

Keywords:Self-regulated learning

\section{INTRODUCTION}

Learning success of the learners certainly depends on the learners' efforts and attitude toward learning. In doing so, the learners are required to be independent and be active learner in seeking anything that they need for their own learning. Regarding to this case, it is expected that the learners enable to implement self-regulated learning for the learners' learning success. Zimmerman (2008, p. 166) asserts, "self-regulated learning is viewed as proactive processes that students use to acquire academic skill, such as setting goals, selecting and deploying strategies, and self-monitoring one's effectiveness".

According to Zimmerman (2008) "self-regulated learning is viewed as proactive processes that students use to acquire academic skill, such as setting goals, selecting and deploying strategies, and self-monitoring one's effectiveness" (p. 166). When the learners implement selfregulated learning, they will learn to arrange goals, set time management, learn strategies, apply self-evaluation, apply self-attributions, apply self-motivation, and seek for help or information on their own to achieve goals that learners want to achieve in learning (Zimmerman, 2002).

When the learners implement self-regulated learning, they will learn to arrange goals, set time management, learn strategies, apply self-evaluation,self-attributions,self-motivation, and seek for help or information on their own to achieve goals that learners want to achieve in learning (Zimmerman, 2002, p. 64). Zimmerman (2002, p. 67) also mentions three cyclical phases of experiencing self-regulated learning including: (1) forethough pahse: occurs before efforts to learn in which the students learn to plan or set goals, (2) performance phase: process that occurs during 
the behavioral implementation in which the learnersimplement the selected methods or strategies that they already set during forethought phase, (3) self-reflection phase: process that occurs after learning effort in which the learners evaluate the effectiveness of each strategy they have already set or planned in helping them to achieve their goals.

Zimmerman (2002, pp. 67-69) also mentions three cyclical phases of experiencing selfregulated learning including:
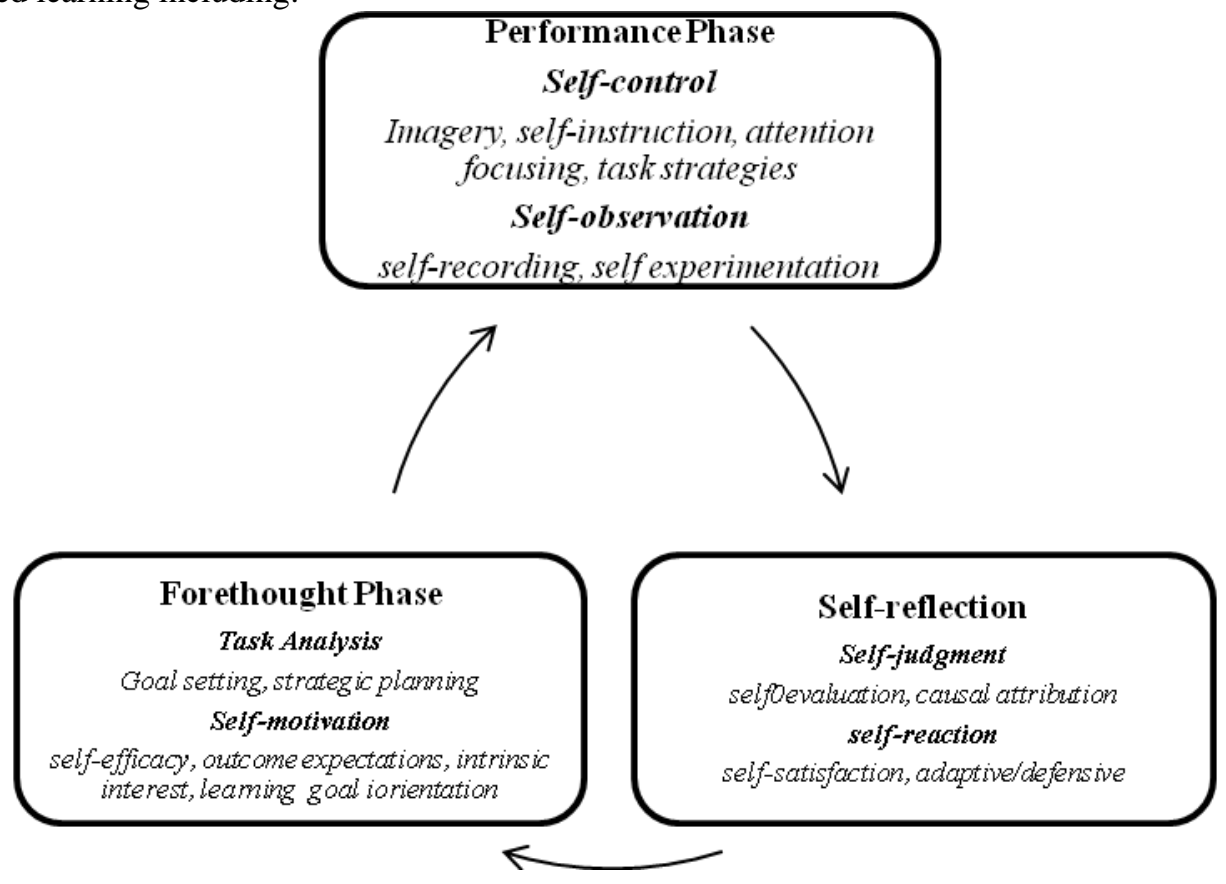

Forethought phase occurs before efforts to learn in which the students learn to plan or set goals. Performance phase is process which occurs during the behavioral implementation in which the learners deploy or implement the selected methods or strategies that they already selected during forethought phases then they will make ongoing adjustments to their plan as they selfmonitor and self -record their progress (doing self-experiment). Meanwhile, self-reflection phases is process that occurs after learning effort in which the learners evaluate the effectiveness of each strategy they have already set or planned in helping them achieve their goals.

This three-phase model of self-regulation has purpose to identify specificmetacognitive processes and motivational sources(Zimmerman \& Moylan, 2009, as cited in Hacker, Dunlosky, \& Graesser, 2009, p. 305). Acording to Zimmerman and Moylan (2009), metacognition refers to knowledge, awareness, regulation of one's thinking in which metacognition is not only about competence but it is also about motivation to explain or influence willingness and effort to learn (as cited in Hacker et al., 2009, p. 299). Moreover, student's efforts to implement self-regulated learning include motivational beliefs and feelings about learning in which this motivational belief influence student's efforts to learn metacognitively. When the students have learnt metacognitively, they certainly have already implemented self regulated learning as metacognition is component of self-regulated learning (Zimmerman \& Moylan, 2009, as cited in Hacker et al., 2009 , p. 299). Thus, it can be concluded that motivation has an important role in student's effort to self-regulate more effectively.

Apart from that, self-regulated learning and motivation are related as motivation is involved in self-regulated learning in which motivation influence goals setting, the strategies chosen for learning, and persistence in a given task (Hadwin 2008, as cited in Mahmoodi, Kalantari, \& Ghaslani, 2014, p. 1066). Camit, Artista, Javelosa, and LaTorre (2014, p. 63)asserts, "motivation directs action to achieve specific goals by manifesting particular behavior".According to Moore (2007), when the students have high motivation, they will tend to optimize their efforts to reach their academic achievements(as cited in Yusri, Romadloni, \& R, 2017, p. 64).

Moreover, both self-regulated learning and motivation work hand in hand to clarify students' learning and success in the classroom (Mahmoodi et al., 2014, p. 1066). When students are motivated to learn, they will set their time and energy needed to learn and apply self-regulated 
learning skills on themselves as strategies for learning (Zimmerman, 2000, as cited in Mahmoodi et al., 2014, p. 1066).

By implementing self-regulated learning, it will give opportunities for the learners to learn by experiences in which this will help them to improved their academic performance and increase the quality of the learners because they have already learnt how to control and do accountability over their own learning start from making plan until doing evaluation and judgment or reflection of thoughts and actions of their own.Noticing the importance of the implementation of selfregulated learning for the development of the learner's cognitive and the success in achieving goals, it is expected that teachers in Indonesia enable to encourage the learners to implement selfregulated learning for the learners' learning success.

Indeed, based on the result of preliminary observation which was conducted in SMPN 2 Singaraja, it had been obtained that not all students in SMPN 2 Singaraja have implemented selfregulated learning. For example, not all students were willing to respond teacher's question, not all students were willing to make a note of teacher's explanation, etc. Therefore, further study on the identification of the implementation of self-regulated learning is certainly needed to be carried out in order to create more resources about the success implementation of self-regulated learning as it is also regarding to the learners' learning success. Hence, the researcher was interested to continue the research to identify the implantation of students' self-regulated learning in all Junior High Schools which have been implementing Curriculum 2013 in Buleleng Sub-district as the implementation of self-regulated learning is closely related to the requirement of the implementation of Curriculum 2013. This research had been conducted in SMPN 1 Singaraja, SMPN 2 Singaraja, and SMPN 4 Singaraja to find outwhetherornotJunior High School students in Buleleng sub-district implement self-regulated learningandWhich aspects of self-regulated learningwhich are mostly implemented by them.

\section{METHODS}

This study belonged to qualitative study by using qualitative analysis. This study was conducted in SMPN 1 Singaraja, SMPN 2 Singaraja, and SMPN 4 Singaraja as those 3 schools have already implemented Curriculum 2013 especially in Buleleng sub-district. A total of 444 students have been chosen as the subject of the study.

In gathering data in order to answer the first research question, which was "do Junior High School students in Buleleng Sub-district implement self-regulated learning?", the data that would be gain was the percentage of self-regulated learning implemented by the students in which the source of the data was questionnaire and the instruments used were human instrument, questionnaire, field note, camera. Moreover, the data would be collected by distributing questionnaire to the subjects and would be analyzed qualitatively.

Next, in order to answer the second research question which was about "which aspects of self-regulated learning in the cyclical phases are mostly implemented by Junior High School students in Buleleng Sub-district?", the data that would be gained was statements which were mostly selected by the students which indicated aspects of selfregulated mostly implemented by the students and also students' reasons behind their motivation in implementing self-regulated learning. The data would be gained from the result of questionnaire and interview in which the instruments used were human instrument, questionnaire, field note, camera, interview guide, and voice recorder. The data would be collected by distributing questionnaire and conducting interview and recording the interview. Finally, the data would be analyzed qualitatively.

Moreover, to find out validity and reliability of the data in this study, the researcher triangulation data based on the theory of Denzin (1978) and Patton (1999) which divided four types of triangulation those are; (a) methodological triangulation, (b) triangulation of sources, (c) analyst triangulation, and (d) theory/perspective triangulation(as cited in Cohen \& Crabtree, 2006). Thus, this study employed methodological triangulation in which this study conducted two methods of collecting the data, those were administrating questionnaires and conducting interview and this study also employed triangulation of sourcesin which this study employed different occasion 
and device. The first data were obtained from administrating questionnaires meanwhile the second data were obtained from interviewing 2-3 students in each schools in which those students were those who only had motivation in implementing self-regulated learning.

\section{RESULTS AND DISCUSSIONS}

The researcher found that a total of $78 \%$ of Junior High School students in Buleleng sub-district have already implemented self-regulated learning. Apart from that, there were two aspects of self-regulated which mostly implemented by the students those were self-judgment and self-reaction in which those two aspects are in self-reflection phase.

In implementing self-judgment, a total of $98 \%$ of the students arewilling to receive feedbacks from either their friends or teachers. The students' reasons of their willingness to receive feedbacks from their friends and teachers were because feedbacks from either their friends or teachers could give positive impact for them in which it could help them to fix mistakes they had done and they would know their weaknesses so then it would help them to improve themselvesbecome better person than before. When they received feedbacks from others, they would like to receive them all, consider all feedbacks given, and implement those all positive feedback given by others in order to help themselves become better than before.

Next, in implementing self-reaction there were two activities were done by the students. First, a total of $97 \%$ of the students will keep learning harder if they get score which is below KKM (Minimum Criterion of Completeness). The students were motivated to keep learning harder if they get score whichbelow KKM (Minimum Criterion of Completeness)because they wanted to improve their score become higher so they would not get lower score below KKM (Minimum Criterion of Completeness) again and they also did want to disappoint their parents. In doing so, the students did other efforts to improve their scores other than just by studying, such as by consulting to parents, taking course outside school hours, looking for material or exercises from other resources, and asking to the teachers or friends about the material which they did not understand. These result were in line with research conducted by Chika, Obodo, and Okafor (2015). They conducted research on exploring the effect of self-regulated learning approach on junior secondary school students' achievement in basic science. They had proven that when students were implementing elf-regulated learning they would do several efforts independently in which they took responsibility of their own learning, they were exposed to learning through exploration, asking question.

Second, it had been found that a total of $97 \%$ of the students would often study and do practices in order to get more satisfactory and maximum results in terms of good or higher scores and good rating as well. Related to those activities that were done by the students, the students also stated their own motivation behind their willingness to learn and practice continuouslyand diligently. The students' motivation comes from inside the students, i.e they want to get good and higher scores and rank as well, and also comes from outside the students, i.e because of their parents in which they want to make their parents happy and satisfy and also because of their friends in which they want to compete with their friends. Those motivations encouraged them to keep learning and spend about 1 until 3 hours to study in a day outside the school hours.

Based on the result of the interview, it can be concluded that the students had their own motivation to implement self-regulated learning on themselves. This result was in line with the research conducted by Mahmoodi, Kalantarib, and Ghaslanic (2014) entitled Self-Regulated Learning (SRL), Motivation and Language Achievement of Iranian EFL Learners. In their research, the findings showed that there was a significant relationship between motivation and self-regulated learning as motivation and self-regulated learning worked closely to simplify EFL learners' learning success in the classroom. 
Apart from that, this result also supported theory of Zimmerman and Moylan (2009) that stated motivational beliefs and feelings about learning influenced student's efforts to learn metacognitively as metacognition refers to knowledge, awareness, regulation of one's thinking in which metacognition it is not about competence but it is also about motivation to explain or influence willingness and effort to learn (as cited in Hacker et al., 2009, p. 299). Thus when the students have learnt metacognitively, they certainly have already implemented self regulated learning as metacognition is component of self-regulated learning.

Furthermore, as the result showed there was relation between motivation and selfregulated learning, this result also supported theory of Hadwin (2008) which states selfregulated learning and motivation are related as motivation is involved in self-regulated learning in which motivation influence goals setting, the strategies chosen for learning, and persistence in a given task (as cited in Mahmoodi et al., 2014, p. 1066).

Apart from that, the researcher also had found self-regulated learning aspects which were mostly not implemented by the students; those were self-observation which is in performance phase and task-analysis which is in forethought phase. In observing selfobservation aspect, it had been obtained that 58.8\% of students were not willing to respond to questions given by teachers during learning activity in the classroom. The students stated they do not actively respond to questions given by teachers during learning activity in the classroom because; (1) they do not know the answer, (2) they feel embarrassed and afraid of giving wrong answers in answering teacher's questions.

Next, in observing task-analysis aspects, two activities were found. First, a total of $49.3 \%$ of students would not seek for learning materials before being taught by the teacher in the classroom. Indeed, the students prefered getting explanation from the teacher first and then look for material that has been taught or explained teacher later on and they also prefered listening to teachers at school only rather than seek for material by themselves. They also stated that they would not seek for learning materials before being taught by the teacher in the classroom because they thoughtthat the lessons were difficult so they will be lazy to find learning materials before being taught by the teacher.

The second activity related to task-analysis aspects was that a total of $58.3 \%$ of the students were not willing to answer the questions in my textbooks before being discussed by the teacher later on in learning activity in the classroom. Indeed, they preferredwaiting for the teacher's explanation in advance to understand the material so then they can answer the questions on the textbook. Apart from that, the students also stated that theywere not willing to answer the questions in my textbooks before being discussed by the teacher because it is difficult to find the answer and they will answer the questions in the textbook if the teacher asks them to do so.

As the findings showed that there were still several students who have not implemented self-regulated learning yet, the teacher and other researcher should think and consider about teaching strategies or methods that can be used to treat students who have not implemented self-regulated learning yet become actively implement selfregulated learning. Furthermore, those teaching strategies or methods are also expected to be able to encourage the students to implement all self-regulated learning aspects in every cyclical phase of self-regulated learning.

\section{CONCLUSION}

The researcher found that a total of $78 \%$ from 444 students in SMPN 1 Singaraja, SMPN 2 Singaraja, and SMPN 4 Singaraja have already implemented self-regulated learning. Apart from that, it was also found that there were two aspects of self-regulated learning which mostly implemented by the students; those were self-judgment and selfreflection in which those 2 aspects are in self-reflection phase.

The other researchers who are interested in the similar topic may use this research result as their empirical review of study. It is also proposed to improve the scope of study 
so the study in order to ring more beneficial effects toward the subject of the study. Apart from that, the researcher also should think and consider about other factors that may affect the result of questionnaires and also think about other instruments which may be needed in order to get more valid data.

\section{REFERENCES}

Ahmad, D. (2014). Understanding the 2013 Curriculum of English Teaching through the Teacherse and Policymakersee Perspectives. International Journal of Enhanced Research in Educational Development (IJERED), 2(4), 6-16.

Camit, A., Artista, L., Javelosa, S., \& LaTorre, J. (2014). The moderating effects of metacognition to the relationship between goal orientation and student motivation in the digital generation. The Asian EFL Journal Professional Teaching Articles, 79(79).

Chika, N., Obodo, A. C., \& Okafor, G. (2015). Effect of Self Regulated Learning Approach on Junior Secondary School Students' Achievement in Basic Science. Journal of Education and Practice, 6(5).

Cohen D, Crabtree B. "Qualitative Research Guidelines Project." July 2006. Available at http://www.qualres.org/HomeTria-3692.html

Filate, A. Y. (2012). The impact of students' self-regulated language learning on their reading achievement: Grade 9 students in focus. ELT Research Journal, 1(3), 175-188.

Froyd, J., \& Simpson, N. (2008, August). Student-centered learning addressing faculty questions about student-centered learning. In Course, Curriculum, Labor, and Improvement Conference, Washington DC, 30 (11).

Hacker, D. J., Dunlosky, J., \& Graesser, A. C. (2009). Handbook of Metacognition in Education. 270 Madison Ave, New York, NY 10016: Routledge.

Johnson, R. B., Onwuegbuzie, A. J., \& Turner, L. A. (2007). Toward a Definition of Mixed Methods Research. Journal of Mixed Methods Research, 1(2), 112-133. doi: 10.1177/1558689806298224

Killen, R. (1966). Effective Teaching Strategies. Australia: Social Science Press.

Mahmoodi, M. H., Kalantari, B., \& Ghaslani, R. (2014). Self-Regulated Learning (SRL), Motivation and Language Achievement of Iranian EFL Learners. Procedia Social and Behavioral Sciences, 98, 1062-1068. doi: 10.1016/j.sbspro.2014.03.517

Oruç, A., \& Arslan, A. (2016). The impact of self-regulated learning on reading comprehension and attitude towards Turkish course and metacognitive thinking. academic journal, 11(8). doi: 10.5897/ERR2016.2692

Prayekti. (2015). Effect of Self-Regulated Learning and Motivation to Achieve Against Teacher Professional Capability for Student S1 PGSD of Science Field Compared with Regular Student S1 PGSD at UPBJJ Serang. Journal of Education and Practice, 6(36).

PERMENDIKBUD No. 70 Tahun 2013 tentang Kerangka Dasar dan Struktur Kurikulum

Salyers, F., \& McKee, C. (2007). The young adolescent learner. Annenberg Media.

UNDANG-UNDANG Republik Indonesia No. 20 Tahun 2003 tentang Sistem Pendidikan Nasional

Wangid, M. N. (2014). STUDENT-CENTERED LEARNING: SELF-REGULATED LEARNING. International Conference on Fundamentals and Implementation of Education (ICFIE).

Yusri, Romadloni, A., \& R, M. (2017). Intercultural approach in foreign language learning to improve students' motivation. The Asian EFL Journal Professional Teaching Articles(98).

Zimmerman, B. J. (2002). Becoming a self-regulated learner: An overview. Theory into practice, 4l(2), 64-70.doi: 10.1207/s15430421tip4102_2 
Zimmerman, B. J. (2008). Investigating Self-Regulation and Motivation: Historical Background, Methodological Developments, and Future Prospects. American Educational Research Journal, 45(1), 166-183. doi: 10.3102/0002831207312909

Zimmerman, B. J., \& Moylan, A. R. (2009). Self-regulation: Where metacognition and motivation intersect. In D. J. Hacker, J. Dunlosky \& A. C. Graesser (Eds.), Handbook of Metacognition in Education (pp. 299-315). New York: Routledge. 